\title{
PROFITABILITY ANALYSIS OF SELECTING INFORMAL INSURANCE MEASURES FOR SELECTED ENTERPRISES BY RURAL FARMERS IN ODOGBOLU LOCAL GOVERNMENT AREA
}

\author{
Ogunmefun S.O., Achike A.I. \\ University of Nigeria, Nsukka, Enugu State, Nigeria \\ E-mail: donoluwilliams@gmail.com, ifyachike@gmail.com
}

\begin{abstract}
This study analyzed the farming systems and other informal insurance measures used by farmers for optimum farm income in Odogbolu Local Government Area of Ogun state, Nigeria. To give effect to the study, eighty farmers were randomly selected from the study area. Data collected through structured questionnaires and interview schedules was analyzed using net farm income analysis. Results showed the gross margin of the farmers who cultivated more than one crop, and reared one poultry or small ruminant animal have more income than those who do not. This research work also showed that rural farmers use different informal insurance measures like diversification of crop and livestock enterprises, contract farming, keeping buffer stock, savings, land fragmentation and others to manage risks that they routinely face. Out of the ten (10) informal insurance measures studied, diversification was the most practiced among the respondents while contract farming is the least used by the respondents. Recommendations include encouraging farmers to adopt the most profitable farming systems and informal insurance measures to help rural people have a stable income.
\end{abstract}

\section{KEY WORDS}

Diversification, contract farming, buffer stock, fragmentation, risks.

Many low-income countries, from Sub-Saharan Africa to Southeast Asia, have suffered major natural disasters and political upheavals through the 1990s. These events remind observers about what is hidden in official poverty statistics: that the condition of poverty is linked closely to vulnerability. Many agrarian households are exposed regularly to risks from poor weather, illness, political instability, and economic mismanagement. Concern with vulnerability may be both intrinsic and tied to implications for income generation, as well as longer-term consequences on the nutrition, health, and schooling of children (Rose, 1995; Hoddinott and Kinsey, 1998; and Jacoby and Skoufias, 1997). Fear of risk can lead agrarian households to forego potentially valuable new technologies and profitable production choices. Rosenzweig and Binswanger (1993), for example, use data from rural South India to show that an increase in risk leads to reductions in farm profits by $35 \%$ for the poorest quarter of households, while the wealthiest (and least vulnerable) farmers are virtually unaffected. Vulnerable households may also spiral downward into ongoing poverty following adverse economic or climatic shocks, as productive assets are depleted to protect consumption levels. Addressing risk can thus be an important complement to redistributive efforts and anti-poverty strategies focused on increasing economic growth and employment. Yet, even with holes in public safety nets and private insurance markets, poor households are not completely exposed to risk. Most have developed coping strategies to deal with the harshest setback. The bulk of mechanisms are provided neither by the market nor the state but instead are "informal insurance," arising between individuals and communities on a personalized basis. Examples include drawing down savings, engaging in reciprocal needbased gift exchange, selling physical assets, and diversifying crops and income-generating activities (Mauss, 1967).

According to Estacio and Mordeno. (2001), agriculture is very much vulnerable to the unpredictability of nature. With agricultural production representing the major source of income of many resource constrained Ogun state farmers, the impact of nature and other agricultural risk cannot be taken lightly. Other agribusinesses and commercial farms that operate with higher capital and better technology on better lands in Odogbolu LGA of Ogun 
state are also not spared from the same risks. The need to safeguard the interests and investments of local farmers and industry players in this region is therefore of paramount importance. Maintaining an increasing flow of income to rural farmers is a challenge to success of poverty alleviation programs in developing economies, due to risks and uncertainties that characterize agricultural activities. Agricultural activities are inherently risky, and smoothing consumption across years or seasons is a significant challenge for agrarian households in developing countries. Farmers and entrepreneurs in rural; agrarian economies therefore should have high demand for credit and insurance services, but the option to purchase such services as credit and insurance facilities often does not exist (Rosenzweig, Mark 1988).

Alderman, Harold and Christina Paxson (1994) are of the opinion that most households in developing countries including Nigeria deal with economic hardships through informal insurance arrangements arising between individuals and communities on a personalized basis, rather than through markets or states. Examples include drawing down savings, engaging in reciprocal gift exchange and diversifying income-generating activities. These mechanisms can be highly effective in the right circumstances, but most recent studies show that informal insurance arrangements are often weak. In particular, poorer households in this area appear to have substantial difficulties coping even with localized, idiosyncratic risks.

In the absence of availability or access to formal insurance mechanisms in Odo LGA, Ogun state, the resource poor farmers seek to manage risks through various informal strategies. They may choose to diversify their crops, store grain, engage in informal savings and credit, favour traditional techniques over modern technology and enter into sharecropping arrangements. Informal insurance is far from perfect as vulnerable groups are faced with varied risks on a recurring basis. It provides only a partial coverage in case of systemic losses, leaving poor producers vulnerable to extreme poverty, malnutrition and also dampens long term agricultural growth. There also seems to be a trade off between market based risk management solutions and public or State sponsored schemes. (IFMR CIRM, 2008).

The vulnerability to income and consumption shocks makes it imperative to develop formal agricultural insurance mechanisms to cope with such risks. The traditional yield insurance schemes and the erstwhile Comprehensive Crop Insurance Scheme (CCIS) have failed to manage the risks of the poor farmers in India, as evident from their historically high payouts and poor penetration rates of State sponsored schemes, which is why this research is set up in Odo LGA of Ogun state, Nigeria, to view the impact and extent to which informal insurance has thrived in this area. Some of the reasons for the failures of formal insurance in India are firstly, Farmers with adequate risk management capabilities were forced to purchase crop insurance in order to receive a loan. Problems were faced especially when the loan is paid up and there was lack of understanding of the benefits of agricultural insurance which leads to a fall in the demand for insurance. Secondly, the 'area approach' followed was based on the results of crop-cutting experiments where the insured farmers receives indemnity based upon the difference between the threshold yield and the yield of the cropcutting experiments in their area. Since crop yields vary over a small area, situations exist in which farmers do not get compensated for their loss under the NAIS and farmers without insurable losses would receive payments. Thirdly, there are long delays in payment of claims to farmers due to the time-consuming crop-cutting experiments by the agriculture department which causes an erosion of income for farmers. Fourthly, physical verification of the losses proved to be very costly and often gave way to fraud as it allows for an opportunity of collusion for the assessor and the client. (IFMR CIRM, 2008)

In view of these deficiencies and the unsustainable role of the State in subsidizing crop insurance which could crowd-out the role of the private sector, index based insurance could be a more efficient means to deal with risks faced in agriculture. For example, farmers could purchase rainfall contracts and if the rainfall in an area varies from a set level, varying levels of payment would be compensated to the respective farmers based upon the level of shortfall of rainfall. This alternate approach as compared to the NAIS would be an effective manner in reducing moral hazard and transaction costs. Innovations in the form of Index-based weather insurance has come up in the past few years to explore possibilities of overcoming some of 
the deficiencies and are being improved on the basis of the feedback from product pilots. (IFMR CIRM, 2008)

Haddad, Lawrence and Manfred Zeller (1996) in their study "How Can Safety Nets do More with Less", warns that some public policies may do little more than crowd out these informal mechanisms, but most evidence on the extent of informal insurance show that these mechanisms are in fact typically weak. Evidence emerging from regions as diverse as rural India, China, and sub-Saharan Africa suggests that households are exposed to considerable risk from adverse shocks - even idiosyncratic shocks that do not simultaneously affect their neighbors. The concern with crowding out is also diminished by the growing awareness that informal insurance can carry heavy economic and social costs. Even if informal mechanisms are effective in reducing vulnerability, they can retard economic growth and social mobility. Thus, even where informal insurance is well-developed, public actions that displace informal mechanisms can yield net benefits.

Jonathan Morduch (1999) opined that the emerging evidence suggests the need for policy concern beyond disaster relief and aid in the face of large, aggregate shocks like floods, earthquakes, droughts, and other natural disasters. Priority should also be given to enabling households to address losses due to illness, poor (local) harvests, and temporary unemployment. This means creating a supportive environment for new institutions that offer safe and reliable means for poor households to borrow and, in particular, to save. Insurance provision is a little-heralded innovation offered by microfinance programs, but recent experience shows that it is possible to offer limited life insurance and protection against other basic exigencies in a simple, low-cost manner (MicroBanking Bulletin 1998). Much more speculatively, it may be possible to improve on existing insurance arrangements for agrarian households by drawing lessons from microfinance analogues. As with the emerging microfinance movement, the actors in the best position to take key roles may often be nongovernmental organizations and profit-making commercial enterprises. Self-regulating public workfare programs like the Employment Guarantee Scheme in Ogun State, Nigeria can also provide households with a flexible means for self-insurance in times of particular need (MicroBanking Bulletin 1998).

This study thus tries to analyze the profitability of selecting various informal insurance measures by rural farmers in Odogbolu Local Government Area of Ogun state, Nigeria.

\section{PROBLEM STATEMENTS}

A distinctive feature of agriculture in developing countries is the level of risk, which is more apparent for those who depend on agriculture for their income. The economic, financial and production shocks which rural farmers are exposed to cause farm profits to vary hence affects the household income of rural farmers. Fluctuations in producers incomes and particularly the threat of catastrophic loss, may present difficult welfare problems for rural farmers. Therefore, the need arises for measures through which rural farmers can protect their household income.

Formal insurance is not fully accepted and adopted by rural farmers because of the cost/premium which needs rural farmers to use a portfolio of risk coping strategies to insure their household income. These measures are used as production practices by farmers. This is the reason why it is difficult to get farmers that do not use at least one informal insurance measure. Therefore, the need to thoroughly examine the risks that occur in agricultural productions and the imitative and coping strategies used by farmers to manage them in their local production so as to reduce their vulnerability to poverty cannot be over emphasized. These risks and the cost effectiveness of informal insurance measures to improve household income have not been subjected to empirical scrutiny, hence this study intends take up this issues and also encourage other researchers to carryout empirical study on the use of informal insurance measures as a risk management strategy by rural farmers in Odo Local Government area of Ogun state. 


\section{OBJECTIVE OF THE STUDY}

The broad objective of the study is to analyze the profitability of selecting various informal insurance measures by rural farmers in Odogbolu Local Government Area of Ogun state, Nigeria.

\section{SIGNIFICANCE OF THE STUDY}

Farmers in Odogbolu LGA of Ogun state are faced with spectrum of risks, and each of these risks along with how they manage them, impact farm income, productivity, and access to credit. Farm level surveys have indicated that the most frequently cited risks are price, crop/weather and health. These risks among others could lower farmers' anticipated income and have negative effects on their standard of living; ability to provide for themselves and their families, ability to build capital, and ability to access credit from lenders. But a well planned informal insurance will help the farmers of this area to prepare for risk and properly manage them.

This research study is relevant to government in that it will suggest the best combinations of policies and programmes for the alleviation of poverty among rural farmers. The informal insurance measures used by farmers need some interventions policies in order to help to protect them and their income against risk. Policies should target those key areas that can help farmers' improve their adoption of these measures. For example, policies should be targeted to the provision of microfinance credit institutions in rural areas in order to assist them in financing their farming activities. Therefore, this study is necessary in suggesting some key areas that need intervention programs to enhance the ability of farmers to manage risk.

\section{LIMITATIONS OF THE STUDY}

In the course of carrying out this study, the researcher encountered problems. These include:

1) The respondents were unwilling to give true information about the revenue they get from their enterprise. They felt the information may be used to tax them.

2) The time for collection of data was short and so the researcher could not get all the information he wanted from the respondents

3) Unavailability of funds was a major problem for the researcher as it restricted my movement to the different areas of the study area.

4) Inability of the farmers to keep records to which made them to guess the cost they incurred and their revenue.

5) Some of the areas in the study area are inaccessible, in terms of roads but rather were accessible through use of boats. This makes the researcher not to collect information from farmers in such areas.

\section{RESEARCH METHODOLOGY}

The study area is Odogbolu Local Government Area and is strategically located on a large expense of land of about 640sq.km and was created on the 21st September 1991 and it shares boundaries on its northern fringes with ljebu-North Local Government, in the east with ljebu-Ode Local Government, in the west with Ikenne Local Government and in the south with Epe Local Government in Lagos State. This Local Government Area has about 150 towns and villages under its jurisdiction. It has 15 wards and its headquarters is in Odogbolu.

Inhabitants of Odogbolu Local Government are Yoruba of ljebu extraction; with a population of 127,000 people according to the 2006 Census. Like any other Nigerian society, there are growing numbers of people from other ethnic groups in the country, such as the Igbos, Isokos, Urhobos, Hausa, etc. Christianity and Islam are the two main religions of the 
people, however there still remain sizeable number of committed traditional worshippers. The Local Government has public primary schools \& secondary schools. There are also an appreciative number of private investments in the education industry. This Local Government Area can boast of a strong traditional heritage and a sound cultural background at the head of which are enlightened royal fathers.

The people in this area are mainly agrarian, engaged in farming, hunting, fishing, lumbering and handicraft. Most of the inhabitants are involved in agriculture although a great percentage of them have other occupations. Some of the food crops grown around the area are yams, cassava maize, rice and vegetables, most of which come from the major agricultural areas in the area. Livestock production is also practiced but mainly on extensive system of production. Poultry production forms the bulk of these livestock activities followed by small ruminant production. Most of the informal insurance measures such as timeliness of operations, diversification etc are practiced as risk management techniques as well as production practices. Also, these farmers keep buffer stock to have something to fall on in case of crop failure and to ensure food security. These traditional methods of managing risks otherwise known as informal insurance measures are used by rural farmers in the study area.

\section{SAMPLING PROCEDURE}

The study was carried out in Odogbolu Local government area of Ogun State, Nigeria. The State was chosen because of its location in the rainforest region and the availability of food crop farmers. Also, studies on food crop farmers in the study area especially as regards issues focusing on risk in agricultural production are scarce in the literature; an attempt to fill this void provides a basis for Odogbolu as the study area.

A two-stage sampling procedure was used in the collection of primary data in Odogbolu LGA. The first stage involved a random selection of five (5) communities from amongst the communities in Odogbolu LGA of Ogun state. The second stage involved the selection of respondents/farmers from each of the communities using the same insurance practices from the already listed informal insurance practices with probability proportionate to the size of each farming communities selected.

\section{DATA COLLECTION}

Data from this study were obtained from both primary and secondary sources. The primary data include the use of questionnaire and oral interview, which were duly administered to the rural farmers. These questionnaires were administered in person due to the little or no formal education of the farmers. The questionnaire schedule provided information on socio-economic characteristics of rural farmers, forms of informal insurance measures used by rural farmers. Data were also collected on the various sources of risk to agricultural products which include nature, social and economic risks.

Data from 80 respondents were used for the analysis. Using structured questionnaires, data used included identification and description of common informal insurance measures, determination of cost and returns to selected enterprise embarked upon by farmers, the relationship between informal insurance measures and risk management and problems and constraints associated with the use of informal insurance measures. Based on the literature, farmers were made to respond to some closed-ended options on questions relating to sources of risk in their respective areas. However, secondary data were also sourced from the Agricultural Development Programme (ADP) office in Ogun state, texts, journal, publications, research reports.

\section{DATA ANALYSIS}

To analyze, identify and determine the common informal insurance practices by rural farmers and the cost / returns of selecting various insurance measures as well as the 
identifying the problems and constraints associated with / against the use of informal insurance measures, analytical tools that were used are mainly descriptive statistics such as mean, frequency, pie charts, percentages, tables and other applicable tools as indicated by responses to the respective survey questions.

\section{COST AND RETURNS ANALYSIS}

The analysis of costs and returns is to indicate the possibility of an enterprise or otherwise to a farmer. Gross margin in crop and livestock enterprises is defined as the differences between revenue (sales) from products obtained from the enterprises and the costs of variable inputs used in production.

Costs of Variable Inputs Used by the Respondents. The sources of variable inputs used for production include the planting materials used by the respondents, labour and other utilities (contingencies) such as ropes, stakes etc. Below is a table showing the average cost/farmer of planting materials, feed, drugs, labour and other contingencies of the respondents.

Table 1 - Distribution of Average Cost/Farmer of the Variable Inputs Used by the Respondents

\begin{tabular}{|l|l|l|}
\hline \multicolumn{1}{|c|}{ Cost of Items } & \multicolumn{1}{|c|}{ Cost farmer (N) } & \multicolumn{1}{c|}{ Percentage } \\
\hline Cassava cuttings & $400 \quad$ & 0.26 \\
\hline Maize seed & 200 & 0.13 \\
\hline Seed yam & 450 & 0.29 \\
\hline Rice seeds & 100 & 0.06 \\
\hline Vegetable seeds & 500 & 0.32 \\
\hline Land preparation & 1500 & 0.96 \\
\hline Planting & 1000 & 0.64 \\
\hline Weeding & 1000 & 0.64 \\
\hline Harvesting & 800 & 0.51 \\
\hline Processing & 600 & 0.38 \\
\hline Breeding stocks & 35,000 & 22.3 \\
\hline Feeds & 60,000 & 38.3 \\
\hline Fertilizers & 5,000 & 3.2 \\
\hline Herbicides & 1200 & 0.8 \\
\hline Other contingencies & 50,000 & 31.9 \\
\hline Total & 156750 & 100 \\
\hline
\end{tabular}

Source: Field survey 2010.

From the above, feed (especially for those in poultry enterprise) has the highest cost/farmer and accounts for $38.3 \%$ of the total cost of production. This follows the findings of Jakob (1989) where he stated that feed accounts $70-85 \%$ of the total cost of production. Maize seed is the least cost. Also cost of breeding stock, labour cost for land preparation and cost of seed yam have higher cost/farmer of N35,000, N1,500 and N450 respectively. The implication of this is that in a production programme of crop which includes yam production, it costs of production is made higher by the higher cost of seed yams. The respondents said that as a result of high cost of seed yams, they keep buffer stocks in order to reduce price risk.

An analysis of costs of production with emphasis on the number of crops and livestock kept by farmers is made in this survey. The essence of this analysis is to assess the cost of production for the respondents according to the number of crops and livestock enterprise they keep as well as their total and average cost of production to show the relevance of the informal insurance measures used by the respondents. Below is a table showing the costs of variable inputs of respondents with different number of crop and livestock enterprise.

The table above shows the pooled and average costs of all variable inputs used by the respondents based on the number of enterprise they embark on. The table shows that the costs of production increases with more diversification of enterprises. 
Table 2 - Distribution of Variable Costs of the Respondents Based on their Number of Crops and livestock

\begin{tabular}{|l|l|l|l|}
\hline Number of Crops and Livestock Enterprises & No. of Farmers & Pooled Costs (N) & Enterprise Average Costs (N) \\
\hline 1 crop \& no livestock & 0 & 0 & 0 \\
\hline ! crop \& 1 livestock & 17 & 55830 & 3284.1 \\
\hline 2 crop \& no livestock & 6 & 64980 & 10830 \\
\hline 2 crops \& 1 livestock & 38 & 109980 & 2894.2 \\
\hline 2 crops \& livestock & 0 & 0 & 0 \\
\hline 3 crops \& no livestock & 3 & 32490 & 10830 \\
\hline 3 crops \& 1 livestock & 14 & 77490 & 5535 \\
\hline 0 crop \& 1 livestock & 2 & 45000 & 22500 \\
\hline Total & 80 & 385,770 & 55873 \\
\hline
\end{tabular}

Source: Field survey 2010.

This is attributed to the fact that the more the diversification the more the input requirements, hence, the increase in cost of production. For instance, the average cost of the respondent with one crop enterprise and one livestock is N55,830 while that of the respondent with 3 corps and one livestock is N77,490. This shows that use of informal insurance measures do not reduce costs of production.

Analysis of Output/Revenue. The output of respondents using informal insurance measures includes the cassava tuber, maize, rice, vegetables, yam, fishes, small ruminants (sheep, goat) and poultry birds. Thus, the table below is a summary of the revenue from these different enterprises according to the particular number of enterprise used by the farmers.

Table 3 - Summary of Respondents Revenue Distribution

\begin{tabular}{|l|l|l|l|}
\hline \multicolumn{1}{|c|}{$\begin{array}{c}\text { Number of Crops and Livestock } \\
\text { Enterprises }\end{array}$} & $\begin{array}{c}\text { No. of } \\
\text { Farmers }\end{array}$ & $\begin{array}{c}\text { Pooled Revenue } \\
(\mathrm{N})\end{array}$ & \multicolumn{1}{|c|}{$\begin{array}{c}\text { Enterprise Average Revenue } \\
(\mathrm{N})\end{array}$} \\
\hline 1 crop \& no livestock & 0 & 0 & 0 \\
\hline crop \& 1 livestock & 17 & 150000 & 8824 \\
\hline 2 crop \& no livestock & 6 & 190000 & $31,666.7$ \\
\hline 2 crops \& 1 livestock & 38 & 350000 & 9210.5 \\
\hline 2 crops \& 2 livestock & 0 & 0 & 0 \\
\hline 3 crops \& no livestock & 3 & 290000 & 96,667 \\
\hline 3 crops \& 1 livestock & 14 & 300000 & 21428.5 \\
\hline 0 crop \& 1 livestock & 2 & 50000 & 25000 \\
\hline Total & 80 & $1,300,000$ & 192,796 \\
\hline
\end{tabular}

Source: Field survey 2010.

From the above, the average revenue/farmer increases with an increase in the number of enterprises of the respondents. This is as a result of the increase in sources of income to the respondents. The least revenue per farmer is from the respondent who grows no crop but has one livestock while the highest revenue was recorded from the respondents who grows two crops and one livestock followed by three crops and one livestock respectively. As the number of informal insurance measures differs among the respondents with different numbers of enterprises, the researcher noted from the respondents that the number of informal insurance measures they use does not increase their revenue but that whatever number used is directed to reducing the occurrence of a particular risk they perceive most while ensuring that their revenue is not affected by such risks. Therefore, the essence of using informal insurance measures by the respondents is to reduce occurrence of crop or livestock failure which affected household income of rural farmers.

Gross Margin. From the average revenue calculated, a gross margin analysis was conducted to determine the reliability of different number of enterprises used by respondents with the number of informal insurance measures used. Below is a table showing the gross margin for the different number of enterprises used by the respondents. 
Table 4 - Gross Margin of Respondents

\begin{tabular}{|l|l|l|l|}
\hline \multicolumn{1}{|c|}{$\begin{array}{c}\text { Number of Crops and Livestock } \\
\text { Enterprises }\end{array}$} & \multicolumn{1}{|c|}{$\begin{array}{c}\text { Average Revenue } \\
(\mathrm{N})\end{array}$} & \multicolumn{1}{|c|}{$\begin{array}{c}\text { Average Costs } \\
(\mathrm{N})\end{array}$} & $\begin{array}{c}\text { Gross Margin Per Farmer } \\
(\mathrm{N})\end{array}$ \\
\hline 1 crop \& no livestock & 0 & 0 & 0 \\
\hline ! crop \& 1 livestock & 8824 & 3284.1 & 5539.9 \\
\hline 2 crop \& no livestock & $31,666.7$ & 10830 & 20836.7 \\
\hline 2 crops \& 1 livestock & 9210.5 & 2894.2 & 6316.3 \\
\hline 2 crops \& 2 livestock & 0 & 0 & 0 \\
\hline 3 crops \& no livestock & 96,667 & 10830 & 85837 \\
\hline 3 crops \& 1 livestock & 21428.5 & 5535 & 15893.5 \\
\hline crop \& 1 livestock & 25000 & 22500 & 2500 \\
\hline Total & 192,796 & 55873 & 136923 \\
\hline
\end{tabular}

Source: Field survey 2010.

The gross margin of the respondents with different number of enterprises is positive in all the diversified crop and livestock enterprises. The implication of this is that the informal insurance measures used to the respondents give a positive trade-off. The gross margin increases from $\mathrm{N} 2500$ for the respondents with only one livestock and no crop enterprise to $\mathrm{N} 20,836.7$ for the respondents with two crop enterprise and no livestock enterprise. This shows that the use of informal insurance measures does not necessarily mean increase in gross margin, but it helps in maintaining a steady flow of income for the farmers.

\section{SUMMARY}

Agriculture is very much vulnerable to the unpredictability of nature. With agricultural production representing the major livelihood of many resource constrained Odogbolu farmers, the impact of agricultural risks cannot be taken lightly. Other agribusinesses and commercial farms that operate with higher capital and better technology on better lands are also not spared from the same risks. The need to safeguard the interests and investments of local farmers and industry players is therefore of paramount importance. Farming is a highrisk business. It is established fact that farmers should use the best seeds, chemicals and management practices, but the weather can still destroy crops. Since one cannot control disasters, it becomes wise to transfer some of the risks by way of insurance in exchange for a manageable premium that can be a part of farmer operating budget.

Household in developing countries continue to face considerable risk, threatening their livelihood. This work discussed the major risk sources which include market failure, price fluctuation, production/yield failure, are highly perceived among the respondents while institutional and financial risks are less perceived. The rural farmers uses different informal insurance measures like diversification of crop and livestock enterprises, contract farming, keeping buffer stock, savings, land fragmentation and others to manage risks that they routinely face. Out of the ten (10) informal insurance measures studied in this survey, diversification is the most practiced form of informal insurance measures among the respondents while contract farming is the least used by the respondents. It showed that for those engaged in both crop and livestock enterprises especially poultry production; costs of feed increases their total of production and also cost of seed yams increases costs of production for respondents that grow yam. Among all the variable inputs used by the respondents, feed accounts for the highest costs $(75-80 \%)$ followed by labour cost for land preparation and the least cost is the cost of vegetable seeds. On the whole, cost of production increases with increase in diversification of enterprises. For revenue, the use of informal insurance measures reduces failure that may lead to loss of revenue but increase in diversification increases revenue. The gross margin is positive for all the enterprises of the respondents. A positive correlation of 0.60 was found to exist between use of informal insurance measures and risk management by the respondents. On the problems encountered by the respondents, they identified factors like lack of access to credit and credit facilities, lack of working capital, lack of skills, high costs of inputs as problems, active as 
entry barriers to their use of informal insurance measures leaving them with low-return and low risk activities.

\section{CONCLUSIONS}

In the absence of availability or little access to formal risk management mechanisms in Odogbolu area of Ogun state, the asset rural households seek to manage risks through various informal strategies. They may choose to diversify their crops, store grain, engage in informal savings and credit, favour traditional techniques over modern technology and enter into share-cropping arrangements. Since the rural farmers are now aware of the use of informal insurance measures, the rural farmers are likely to engage in low risk, low return activity portfolios. This is not because the rural farmers have different inmate preferences $-\mathrm{a}$ psychological trait that makes them less entrepreneurial. Diversifying income sources is useful but because rural farmers are poor, it may come at a high cost, in terms of levels of income and procurement of inputs. Nevertheless, observing specialization does not necessarily imply that the household follows a high risk strategy. Poverty allocation strategy should not focus only on reducing the head count poverty rate or the percentage of rural households to total population. Policy objective should be to reduce the level of vulnerability to poverty by providing mechanisms for the rural farmers to manage risk.

\section{RECOMMENDATIONS}

The effectiveness of risk management of rural farm households is an empirical issue. The essence of carrying out a survey on the use of informal insurance measures among rural farmers in managing risks is to show the effectiveness of using these measures as well as identify the problems they may encounter. Promoting diversification is not necessarily a solution but finding ways of reducing constraints into profitable low-risk activities.

Based on these findings, I recommend the following factors to be adopted to improve the effectiveness of using informal insurance measures by rural farmers.

1) Government should make prudent monetary and fiscal policies that help, in controlling inflation, and reduces the risk of falling real income. Such policies help rural farmers to improve their ability to manage risk effectively, tackle price and production risk which rural farmers face majorly.

2) From this findings, it was revealed that informal insurance management practices used by the respondent did not increase the revenue of the rural farmers, this was due to the little holdings of the farmers and little investment in agriculture, therefore, the farmers should be encouraged to invest more and increase their input in agriculture as to improve their output/revenue.

3) The government should give concessions to the rural farmers in various aspects which include provision of credit facilities, provision of infrastructures and inputs for rural farmers to enable them perform most of the informal insurance measures.

\section{REFERENCES}

1. Ainsworth, Martha (1996), "Economic Aspects of Child Fostering in Cote D'Ivoire," in T. Paul Schultz, ed., Research in Population Economics, vol. 8, Greenwich, CT: JAI Press, 25 -62 .

2. Akintola JO (1999), Forecasting food crop yields from meteorological variables. J.of Econs. and Social Development Vol. 14, No.1, 24-33.

3. Alderman, Harold (1996), "Saving and Economic Shocks In Rural Pakistan," Journal of Development Economics 51(2) 343-366.

4. Alderman, Harold and Christina Paxson (1994), "Do the Poor Insure? A Synthesis of the Literature on Risk Sharing Institutions in Developing Countries," in Economics in a Changing World: Proceedings of the Tenth World Congress of the International Economics Association, Moscow, London: MacMillan Press. 
5. Amaza PS and JK Olayemi (1993), An investigation of production efficiency in food crop enterprises, Gombe state

6. Anand, Sudhir and Jonathan Morduch (1999), "Poverty and the 'Population Problem'," in Gustavo de Santis and Massimo Livi-Bacci, eds., Population and Poverty in the Developing World. Oxford: Oxford University Press/IUSSP.

7. Banerjee, Abhijit and Andrew Newman (1998), "Information, the Dual Economy, and Development," Review of Economic Studies 65 (4), October: 631 - 654.

8. Baquet $A$, Hambleton $R$ and $D$ Jose Introduction to risk management. In: Wesley, N.M., George, F.P. and Ullerich, S. (2002). Demonstrating differences in risk attitudes, J. of American Society of Farm Managers and Rural Appraisers ASFMRA

9. Bencivenga, Valerie, and Bruce D. Smith (1991), "Financial Intermediation and Endogenous Growth," Review of Economic Studies 58(2): 195 - 209.

10. Besley, Timothy (1995a), "Non-Market Institutions for Credit and Risk-Sharing in LowIncome Countries," Journal of Economic Perspectives 9 (3), 115 - 127.

11. Besley, Timothy (1995b), "Savings, Credit, and Insurance," in Jere Behrman and T.N. Srinivasan, eds., Handbook of Development Economics, vol. 3. Amsterdam: North-Holland.

12. Bledsoe, Caroline H. and U. C. Isiugo-Abanihe (1989), "Strategies of Child Fosterage among Mende Grannies in Sierra Leone," in R. Lesthaeghe, ed., African Reproduction and Social Organization, Berkeley, CA: University of California Press.

13. Case, Anne and Angus Deaton (1998), "Large Cash Transfers to the Elderly in South Africa," Economic Journal 108 (450), 1330 - 1361

14. Coate, Stephen and Martin Ravallion (1993), "Reciprocity without Commitment: Characterization and Performance of Informal Insurance Arrangements," Journal of Development Economics 40 (1), February, 1 - 24.

15. Cochrane, John (1991), "A Simple Test of Consumption Insurance," Journal of Political Economy 99 (5), $957-976.33$

16. Corbett J (1988), Famine and household coping strategies. In: World Development, vol. 16, No. 9,1099-1112

17. Cox, Donald and Emmanuel Jimenez (1997), "Coping with Apartheid: Inter-Household Transfers over the Life-Cycle in South Africa," Boston College and World Bank, draft.

18. Cox, Donald and Emmanuel Jimenez (1998), "Risk-Sharing and Private Transfers: What about Urban Households?" Economic Development and Cultural Change 46 (3), April, 621 -639 .

19. CSAE, (2000). Income and Intra-village Consumption Smoothing. Preliminary Draft. Research Program in Development Students. Princeton University.

20. Czukas, Katherine, Marcel Fafchamps, Christopher Udry (1998), "Drought and Saving in West Africa: Are Livestock a Buffer Stock?" Journal of Development Economics 55(2), 273 305.

21. Das Gupta, Monica (1987), "Informal Security Mechanisms and Population Retention in Rural India," Economic Development and Cultural Change 13 (1), March, $101-120$.

22. Deaton, Angus (1997), The Analysis of Household Surveys. Baltimore: World Bank/Johns Hopkins University Press.

23. Dismukes R (2005), Farm risk management http//www.ers.usda.gov/Briefing/risk Management.

24. Fafchamps, Marcel (1992), "Solidarity Networks in Preindustrial Societies: Rational Peasants with a Moral Economy," Economic Development and Cultural Change 41 (1), October, $147-173$.

25. Foster, Andrew and Mark Rosenzweig (1999), "Imperfect Commitment, Altruism and the Family: Evidence from Transfer Behavior in Low-Income Areas," Department of Economics, University of Pennsylvania, draft.

26. Gertler, Paul and Jonathan Gruber (1997), "Insuring Consumption Against Illness." Cambridge, MA: NBER Working Paper 6035.

27. Hardaker, J. b,, Huirne, R. B. M and Anderson, J. R. (1997). Coping with Risk in Agriculture. Washington: CAB International. pp.32-34. 
28. Haddad, Lawrence and Manfred Zeller (1996), "How Can Safety Nets do More with Less? General Issues with Some Evidence from Southern Africa," FCND Discussion Paper 16, IFPRI, Washington, DC.

29. Harwood J, Heifner R, Coble K, Perry T and A Somwaru (1999), Managing risk in farming: concepts, research and analysis. Agric. Econs. Report No. 774. Market and Trade Economic Division and Resource Economics Division, Economic Research Service U.S.Department of Agriculture.

30. Hoff, Karla (1997), "Informal Insurance and the Poverty Trap," Dept. of Economics, University of Maryland, draft, January.

31. Institute for Financial Management and Research (IFMR CIRM) - Centre for Insurance and Risk Management (2008). An International Agricultural Journal.

32. Isik M (2002) Resource Management under Production and Output Price Uncertainty. Implication for Environmental Policy. American J. of Agric. Econs. 84 (3), 557-591.

33. Jacoby, Hanan and Emmanuel Skoufias (1997), "Risk, Financial Markets, and Human Capital in a Developing Country," Review of Economic Studies 64 (3), July, 311 -336.

34. Jalan, Jyotsna and Martin Ravallion (1997), "Are the Poor Less Well Insured? Evidence on Vulnerability to Income Risk in Rural China," World Bank working paper, draft.

35. Jensen, Robert (1998), "Public Transfers, Private Transfers, and the 'Crowding Out' Hypothesis: Theory and Evidence from South Africa," John F. Kennedy School of Government Faculty Working Paper Series, R98-08, June.

36. Jonathan Morduch (1999) Between the Market and State: Can Informal Insurance Patch the Safety Net? Summer Research Workshop on Poverty, Washington DC.

37. Khandker, Shahidur (1998), Fighting Poverty with Microcredit: Experience in Bangladesh. New York: Oxford University Press and The World Bank.

38. Kletzer, Kenneth and Brian Wright (1998), "Sovereign Debt as Intertemporal Barter," University of California, Berkeley, Center for International and Development Economics Research Working Paper C98-100.

39. Kochar, Anjini (1999), "Smoothing Consumption by Smoothing Income: Hours-of-Work Responses to Idiosyncratic Agricultural Shocks in Rural India," Review of Economics and Statistics 81 (1), February, $50-61$.

40. La Ferrara, Eliana (1997), "Ethnicity and Reciprocity: An Analysis of Credit Transactions in Ghana," Dept. of Economics, Harvard University, draft.

41. Ligon, Ethan, Jonathan Thomas, and Tim Worall (1997), "Informal Insurance Arrangements in Village Economies," Dept. of Agricultural and Resources Economics, draft, January.

42. Lim, Youngjae and Robert Townsend (1998), "General Equilibrium Models of Financial Systems: Theory and Measurement in Village Economies," Review of Economic Dynamics 1 (1), January, 59 - 118.

43. Lipton, Michael and Martin Ravallion (1993), "Poverty and Policy," in Jere Behrman and T.N. Srinivasan, eds., Handbook of Development Economics, vol. 3. Amsterdam: NorthHolland.

44. Lucas, Robert E.B. and Oded Stark (1985), "Motivations to Remit: Evidence fromBotswana," Journal of Political Economy 93 (5), October, 901 - 918.

45. Lund, Susan and Marcel Fafchamps (1997), "Risk-Sharing Networks in Rural Philippines," Department of Economics, Stanford University, draft.

46. Mauss, Marcel (1967), The Gift. New York: W.W. Norton.

47. Meuwisssen, M. P. M., Huirne, B. M and Hardaker, J. B. (1999). Income Insurance for Individual Farmers: Feasibility for European Agriculture Organized Session Papers. IXEuropean Congress for Agricultural Economists, pp.428-444.

48. MicroBanking Bulletin (1998), July. Boulder, CO: Economics Institute

49. Morduch, Jonathan (1995), "Income Smoothing and Consumption Smoothing," Journal of Economic Perspectives 9 (3), Summer, 103 - 114.

50. Morduch, Jonathan, (1994), "Poverty and Vulnerability," American Economic Review 84, May: $221-225$.

51. Morris, Morris D. (1974), "What is a Famine?" Economic and Political Weekly (Bombay), November. 
52. Newbery, David and Joseph Stiglitz (1981), The Theory of Commodity Price Stabilization. Oxford: Oxford University Press.36

53. Okunmadewa F (2003) Risk, vulnerability in agriculture: concept and context. A paper presented at staff seminar, Department of Agricultural Economics. , University of Ibadan.

54. Olayide SO and EO Heady (2000) Introduction to agricultural production economics, Ibadan University Press Publishing House, University of Ibadan

55. OSSADEP (1992-2001). Osun state agricultural development programme, Annual Reports.

56. Paulson, Anna (1995), "Insurance Motives for Migration: Evidence from Thailand," Princeton University, draft.

57. Platteau, Jean-Philippe and Anita Abraham (1987), "An Inquiry into Quasi-Credit Contracts: The Role of Reciprocal Credit and Interlinked Deals in Small-Scale Fishing Communities," Journal of Development Studies 23 (4): 461 - 490.

58. Ravallion, Martin (1991), "Reaching the Rural Poor Through Public Employment: Arguments, Evidence, and Lessons from South Asia," World Bank Research Observer 6 (2), $153-175$.

59. Ravallion, Martin and Shubham Chaudhuri (1996), "Risk and Insurance in Village India: Comment," Econometrica.

60. Ray PK (1980) Agricultural insurance: principles, organization and application to developing countries. 2nd Edition, Pergamon Press, Oxford England.

61. Reardon, T, Stamoulis, K. Cruz, M. E. Balisacan, A., Berdegue, J. and Banks, B. (1998). Rural Non-farm Incomes in Developing Countries In: The State of Food and Agriculture. FAO Agric. Series No.31, pp.8-10.

62. Rose, Elaina (1995), "Consumption Smoothing and Excess Female Mortality in Rural India," Review of Economics and Statistics 81 (1), February, 41 - 49.

63. Rosenzweig, Mark and Kenneth Wolpin (1993), "Credit Market Constraints, Consumption Smoothing, and the Accumulation of Durable Production Assets in Low-Income Countries: Investment in Bullocks in India," Journal of Political Economy 101 (2), April: 223 - 244.

64. Rutherford, Stuart (1999), "The Poor and Their Money," Finance and Development Research Programme Working Paper Series 3/99. Manchester, UK: University of Manchester Institute for Development Policy and Management.

65. Skoufias, E. and Quisumbing, A. R. (2003). Consumption, Insurance and Vulnerability to Poverty: A Synthesis of the Evidence from Bangladesh, Ethiopia, Mali, Mexico and Russia.

66. Steel, William F., Ernest Aryeetey, Hemamala Hettige and Machiko Nissanke (1997), "Informal Financial Markets Under Liberalization in Four African Countries," World Development 25 (2), $817-830$.

67. Subbarao, K., Aniruddha Bonnerjee, Jeanine Braithwaite, Soniya Carvalho, Kene Ezemenari, Carol Graham, and Alan Thompson (1997), Safety Net Programs and Poverty Reduction: Lessons from Cross-Country Experience. Washington, DC: The World Bank.

68. Timmer, C. Peter (1987), "Food Price Policy in Indonesia," Harvard HIID Development Discussion Paper 250, November.

69. Upton M (1996). The Economics of Tropical Farming Systems. Cambridge University Press.

70. USDA, Economic Research Service (1999). Managing Risk in Farming: Concepts, Research and Analysis. Washington DC.

71. Walker, Thomas, R. P. Singh, and M. Asokan (1986), "Risk Benefits, Crop Insurance, and Dryland Agriculture," Economic and Political Weekly 21, June, A81 - A88.

72. World Bank (2001) Dynamic risk management and the poor: developing a social protection strategy for Africa", Africa Region Human Development Series. Washington DC, USA.

73. Yaron, Jacob, McDonald Benjamin, and Gerda Piprek (1997), Rural Finance: Issues, Design, and Best Practices. Washington, D.C., World Bank, draft.

74. Zeller, Manfred, Gertrud Shrieder, Joachim von Braun, and Franz Heidhues (1997), Rural Finance for Food Security for the Poor. Food Policy Review 4, Washington, D.C.: IFPRI. 